\title{
IMPLEMENTASI KURIKULUM 2013 TINGKAT PENDIDIKAN DASAR MADRASAH IBTIDAIYAH NEGERI (MIN) DI KABUPATEN ACEH SELATAN
}

\author{
Masni, Hanifuddin Jamin dan Maya Agustina \\ Program Studi PGMI STAIN Teungku Dirundeng Meulaboh \\ Email Penulis 1; masni@staindirundeng.ac.id 2; hanifstainmbo@gmail.com 3; \\ mayaagustn@staindirundeng.ac.id
}

\begin{abstract}
Abstrak
Telah dilakukan penelitian tentang "Implementasi Kurikulum 2013 Tingkat Sekolah Dasar Madrasah Ibtidaiyah Negeri (MIN) di Kabupaten Aceh Selatan”. Penelitian ini dilakukan di MIN se-Kabupaten Aceh Selatan dengan jumlah lokasi penelitian di 27 MIN. Penelitian ini dilakukan dengan metode triangulation of research, blending or mixing a qualitative and quantitative. Pemilihan sampel penelitian dilakukan secara random sampling. Tahapan penelitian meliputi penyebaran instrumen penelitian berupa penyebaran angket untuk diisi oleh guru selanjutnya melakukan observasi sekaligus melakukan wawancara dengan kepala dan guru-guru di MIN. Hasil angket tingkat keberhasilan implementasi kurikulum 2013 menunjukkan kategori "sedang" dengan persentase sebesar 69,50\%, sedangkan untuk tingkat kategori "tinggi" dan "rendah" masing-masing menunjukkan angka 6,78\%. Hasil wawancara dengan Kepala dan guru MIN diketahui bahwa, implementasi kurikulum 2013 di MIN seKabupaten Aceh Selatan sudah diterapkan selama 3 tahun khusus pada mata pelajaran Pendidikan Agama Islam (PAI). Kendala-kendala yang dihadapi oleh guru-guru MIN di Kabupaten Aceh selatan yaitu kurangnya pemahaman guru tentang implementasi proses belajar mengajar, desain perangkat pembelajaran, terbatasnnya sarana dan prasarana pendukung, penguasaan IT serta penggunaan aplikasi evaluasi kurikulum 2013.
\end{abstract}

Kata Kunci: Implementasi, Kurikulum 2013, MIN

\section{Abstract}

Research was carried out on the subject of "Implementation of the 2013 curriculum for the elementary level of the State Islamic Middle School (MIN) in South Aceh Regency". This research was conducted at MIN in the South Aceh Regency and included up to 27 MINs. This research was conducted using a triangulation of research method, blending or mixing a qualitative and quantitative. The selection of the research sample was done by random sampling. The stages of the research include the distribution of research instruments in the form of questionnaires to be filled out by the teacher, subsequent observations and interviews with the headmaster and the teachers of the MIN. The results of the questionnaire on the success rate of curriculum implementation in 2013 showed the "medium" category with a percentage of $69.50 \%$, while for the "high" and "low" categories, each showed a figure of $6.78 \%$. The results of interviews with school principals and MIN teachers revealed that the implementation of the 2013 curriculum in MIN in South Aceh Regency had been applied for 3 years specifically for Islamic Religious Education (PAI) subjects. The obstacles MIN teachers face in the South Aceh Regency area are the teachers' lack of understanding of the implementation of the teaching and learning process, the design of learning devices, limited facilities and supporting infrastructure, IT mastery and the use of 2013 curriculum evaluation applications.

Keywords: Implementation, Curriculum 2013, State Islamic Elementary School 


\section{PENDAHULUAN}

Undang-Undang RI No. 20 tahun 2003 tentang Sistem Pendidikan Nasional menjelaskan bahwa: Pendidikan adalah usaha sadar dan terencana untuk mewujudkan suasana belajar dan proses pembelajaran agar peserta didik secara aktif mengembangkan potensi dirinya untuk memiliki kekuatan spiritual keagamaan, pengendalian diri, kepribadian, kecerdasan, akhlak mulia, serta ketrampilan yang diperlukan dirinya, masyarakat, bangsa dan Negara (UndangUndang SISDIKNAS, 2006:2).

Pemerintah Indonesia dari masa ke masa terus berusaha untuk mewujudkan tujuan dari Undang-Undang RI No.20 tahun 2003 tentang Sistem Pendidikan Nasional tersebut salah satunya yaitu dengan menerapkan kurikulum 2013. Kurikulum (Imas Kurinasih dan Berlin Sani, 2014:3) ini diharapkan akan mampu membawa perubahan seiring dengan tantangan dalam menyiapkan sumber daya manusia yang berkualitas dan berdaya saing di era global.

Konsep kurikulum 2013 sangat mengutamakan peran aktif peserta didik sebagai subjek bukan lagi sebagai objek dalam memahami setiap materi ajar. Peserta didik dituntut agar selalu kreatif dalam menemukan setiap poin ilmu pengetahuan dengan mengunakan cara pandang atau pola fikir mereka sendiri, sehingga mereka selalu bisa mengeluarkan berbagai bentuk ide/pendapat ataupun analisis mereka yang dibantu oleh guru dengan menggunakan metode pembelajaran kolaborasi (Imas Kurinasih dan Berlin Sani, 2014:43) atau dengan menggunakan beragam metode multimodel pembelajaran.

Sebuah kurikulum yang baik tentunya memiliki standar yang berbeda dari kurikulum sebelumnya. Pengembangan dan perubahan dari satu kurikulum ke kurikulum lainnya merupakan salah satu usaha agar mutu pendidikan semakin meningkat. Pencapaian keberhasilan sebuah kurikulum sangat dipengaruhi oleh tahapan yang dilakukan ketika sebuah kurikulum diimplementasikan. Adapun tahapan keberhasilan kurikulum (Imas Kurinasih dan Berlin Sani, 2014:7-9) yang dimaksud yaitu :

1. Adanya sosialisasi yang menyeluruh yaitu; Memberitahukan atau menginformasikan suatu perubahan kurikulum kepada semua pihak yang berkepentingan dibidang pendidikan. Penyebaran informasi tersebut bertujuan untuk memberikan pemahaman kepada semua pihak seperti semua guru, siswa dan orang tua.

2. Selalu menghadirkan lingkungan yang kondusif yaitu; Lingkungan yang menjadi salah satu pendukung agar penerapan kurikulum bisa optimal. Lingkungan kondusif yang dimaksudkan yaitu tersedianya tempat/sarana yang nyaman, aman dan tertib untuk menarik minat dan motivasi belajar dalam proses pembelajaran.

3. Selalu mengembangkan fasilitas dan sumber belajar yaitu fasilitas belajar yang memadai juga diperlukan dalam mendukung keberhasilan implementasi sebuah kurikulum. Fasilitas yang dimaksudkan seperti laboratorium, buku-buku pedoman yang up to date, internet yang memadai, perpustakaan yang lengkap dengan sumber belajar yang diinginkan untuk membantu siswa dalam berkreasi.

4. Memupuk dan mengembangkan kemandirian sekolah yatitu; Peran kepala sekolah sebagai koordinator dan pengatur suatu lembaga sekolah sangatlah penting agar visi dan misi sekolah dapat terwujud. Visi dan misi sekolah dapat diwujudkan melalui penerapan program-program yang telah direncanakan secara bertahap dan terencana.

5. Meluruskan paradigma pola pikir guru yaitu; meluruskan persepsi atau pemahaman setiap guru berbeda-beda sesuai dengan informasi yang diperoleh masing-masing guru adanya adanya pelatihan dan penataran khusus mengenai kurikulum yang akan diberlakukan sehingga guru memiliki pemahaman yang sama. 
6. Memberdayakan semua tenaga kependidikan yaitu; guru dan tenaga kependidikan perlu diberi pemahaman tentang kurikulum yang baru dan memiliki kemampuan manajerial yang baik agar mampu penerapan sebuah kurikulum agar optimal.

Kemudian, Pengembangan kurikulum 2013 juga memiliki beberapa landasan/kerangka dasar mulai dari tahap perencanaan hingga implementasinya. Yang menjadi landasan dasar atau pondasi awal terwujudnya kurikulum 2013, yaitu:

1. Landasan Filosofis yaitu pengembangan kurikulum 2013 dengan landasan filosofis yang memberikan dasar bagi pengembangan seluruh potensi peserta didik menjadi manusia Indonesia berkualitas yang tercantum dalam tujuan pendidikan nasional. Landasan Filosofis yang merupakan landasan awal yang merujuk pada falsafah Pancasila sebagai dasar Negara dan UU nomor 20 Tahun 2003 (Undang-Undang SISDIKNAS Nomor 20 Tahun 2003, 2006:2) tentang Sistem Pendidikan Nasional. Pada dasarnya tidak ada satupun filosofi pendidikan yang dapat digunakan secara spesifik untuk pengembangan kurikulum yang dapat menghasilkan manusia yang berkualitas.

2. Landasan Sosiologis adalah salah satu tujuan pendidikan adalah mempersiapkan peserta didik yang mampu hidup dalam kehidupan bermasyarakat (Zainal Arifin, 2012:65). Oleh karena itu, Kurikulum 2013 dikembangkan atas dasar adanya kebutuhan akan perubahan rancangan dan proses pendidikan dalam rangka memenuhi dinamika kehidupan masyarakat, bangsa, dan negara, sebagaimana termaktub dalam tujuan pendidikan nasional. Pada dasarnya masyarakat adalah sebuah lembaga dan sebuah sistem pendidikan yang memiliki tiga konsep yang menjadi unsur penting pendidikan yaitu; masyarakat memiliki nila-nilai budaya dan kebiasaan, masyarakat memiliki nilai-nilai sosial dan gotong royong (kebersamaan), serta memiliki nilai-nilai kepribadian.

3. Landasan Psikologis adalah Landasan kurikulum yang dipengaruhi oleh kondisi psikologis individu yang terlibat di dalamnya (Zainal Arifin, 2012:56), karena setiap proses pembelajaran akan menuntut peserta didik untuk memiliki kemauan, kematangan dan kesiapan untuk belajar. Kurikulum 2013 dimaksudkan untuk memenuhi tuntutan perwujudan konsepsi pendidikan yang bersumbu pada perkembangan peserta didik beserta konteks kepribadiannya sebagaimana dimaknai dalam konsepsi Psikologis.

4. Landasan Teoritis yaitu sebagaimana yang terdapat dalam Peraturan Pemerintah nomor 19 Tahun 2005 tentang Standar Nasional Pendidikan (SNP), yang telah disempurnakan dalam Peraturan Pemerintah nomor 32 Tahun 2013 (E. Mulyasa, 2016:22). Kurikulum 2013 dikembangkan atas teori "pendidikan berdasarkan standar" (standard-based education), dan teori kurikulum berbasis kompetensi (competency-based curriculum). Pendidikan berdasarkan standar menetapkan adanya standar nasional sebagai kualitas minimal warganegara yang dirinci menjadi standar isi, standar proses, standar kompetensi lulusan, standar pendidik dan tenaga kependidikan, standar sarana dan prasarana, standar pengelolaan, standar pembiayaan, dan standar penilaian pendidikan. Kurikulum berbasis kompetensi dirancang untuk memberikan pengalaman belajar seluas-luasnya bagi peserta didik dalam mengembangkan kemampuan untuk bersikap, berpengetahuan, berketerampilan, dan bertindak.

5. Landasan yuridis yaiitu; landasan yuridis merupakan ketentuan hukum yang dijadikan dasar untuk pengembangan kurikulum. Landasan yuridis merupakan salah satu landasan yang menjadi acuan dalam segala proses dan pelaksanaan kurikulum pendidikan, sabagaimana yang terdapat dalam Permendikbud Nomor 65 Tahun 2013 (Permendikbud Nomor 65 Tahun 2013) tentang standar proses Pendidikan Dasar dan Menengah serta penetapan perangkat pembelajaran seperti; silabus, RPP dan sistem evaluasi pembelajaran. Kemudian dalam Permendikbud Nomor 71 Tahun 2013 dijelaskan tentang buku teks pelajaran yang dibagi dalam dua paket yaitu buku teks pelajaran yang menjadi pegangan peserta didik dan buku teks pelajaran yang menjadi pegangan guru, sehingga buku teks 
pelajaran tersebut harus mampu dikuasai oleh masing-masing guru bidang studi dalam proses belajar mengajar. Landasan yuridis Kurikulum 2013 adalah:

a. Undang-Undang Dasar Negara Republik Indonesia Tahun 1945;

b. Undang-undang Nomor 20 Tahun 2003 tentang Sistem Pendidikan Nasional;

c. Undang-undang Nomor 17 Tahun 2005 tentang Rencana Pembangunan Jangka Panjang Nasional, beserta segala ketentuan yang dituangkan Rencana Pembangunan Jangka Menengah Nasional;

d. Peraturan Pemerintah Nomor 19 Tahun 2005 tentang Standar Nasional Pendidikan sebagaimana telah diubah dengan Peraturan Pemerintah Nomor 32 Tahun 2013 tentang Perubahan Atas Peraturan Pemerintah Nomor 19 Tahun 2005 tentang Standar Nasional Pendidikan.

e. Undang-undang No 20 tahun 2003 tentang Sistem Pendidikan Nasional;

f. PP No 19 tahun 2005 tentang Standar Nasional Pendidikan;

g. PP No 23 tahun 2013 tentang Perubahan Standar Nasional Pendidikan;

h. Permendikbud No 54 tahun 2013 tentang Standar Kompetensi Lulusan;

i. Permendikbud No 64 tahun 2013 tentang Standar Isi;

j. Permendikbud No 65 tahun 2013 tentang Standar Proses;

k. Permendikbud No 66 tahun 2013 tentang Standar Penilaian;

1. Permendikbud No 67 tahun 2013 tentang Kerangka Dasar Kurikulum Kompetensi $\mathrm{SD}$;

m. Permendikbud No 68 tahun 2013 tentang Kerangka Dasar Kurikulum Kompetensi SMP;

n. Permendikbud No 69 tahun 2013 tentang Kerangka Dasar Kurikulum Kompetensi SMA;

o. Permendikbud No 70 tahun 2013 tentang Kerangka Dasar Kurikulum Kompetensi SMK;

p. Permendikbud No 71 tahun 2013 tentang Buku Teks Pelajaran Layak (Imas Kurinasih dan Berlin Sani, 2014:35).

6. Landasan empiris merupakan landasan yang mengarah pada adanya kerja sama antara guru, orang tua dari peserta didik dan masyarakat dalam setiap proses pelaksanaan pendidikan. Hal ini sesuai dengan Undang-Undang RI No. 20 tahun 2003 tentang Sistem Pendidikan Nasional pasal 7 (Undang-Undang RI No. 20 tahun 2003, 2006:7) yang menjelaskan tentang hak-hak orang tua untuk mendapatkan informasi tentang perkembangan pendidikan anaknya dari para praktisi pendidikan serta kewajiban orang tua sebagai pendidik utama untuk memberikan pendidikan dasar terlebih dahulu di dalam keluarga kepada anak-anak mereka.

\section{KAJIAN TEORITIS}

\section{Desain Pembelajaran Kurikulum 2013}

Desain sistem pembelajaran dalam konteks kurikulum 2013 harus diawali dengan kegiatan studi pendahuluan untuk merumuskan tujuan pembelajaran. Berdasarkan tahapan pengembangan tersebut, guna menghasilkan tujuan pembelajaran yang harus dicapai siswa setelah mengikuti proses pembelajaran dalam konteks kurikulum 2013, analisis kebutuhan tujuan harus dilakukan dengan mengkaji performa apa yang harus dimiliki siswa dalam kaitannya dengan tuntutan belajar abad ke-21. Kajian atas performa ini menjadi dasar bahwa pembelajaran dalam konteks kurikulum 2013 haruslah senantiasa diorientasikan bagi pengembangan performa siswa meliputi performa cerdas, tangkas, dan terampil dalam berkomunikasi, berkolaborasi, dan ber-IT. 
Dalam kaitannya dengan analisis kebutuhan pembelajaran dalam konteks kurikulum 2013 harus mampu menghasilkan lulusan yang relevan dengan tuntutan belajar abad ke-21 yakni terampil belajar dan berinovasi. Keterampilan ini berkenaan dengan kemampuan berpikir kritis dan kemampuan memecahkan masalah, kemampuan berkomunikasi dan berkolaborasi, dan kemampuan untuk berkreativitas dan berinovasi. Ketiga keterampilan ini diyakini merupakan keterampilan utama yang dapat menjawab berbagai tantangan hidup baik dari dimensi ekonomi, sosial, politik maupun dimensi pendidikan.

Standar lulusan kurikulum 2013 telah diatur melalui Permendikbud Nomor 54 Tahun 2013 tentang Standar Kompetensi Lulusan Pendidikan Dasar dan Menengah (Peraturan Menteri Pendidikan dan Kebudayaan Nomor 54 Tahun 2013). Kompetensi lulusan merupakan kualifikasi kemampuan lulusan yang mencakup sikap, pengetahuan, dan keterampilan, yang akan menjadi acuan bagi pengembangan kurikulum dalam rangka mewujudkan tujuan pendidikan nasional. Penetapan pendekatan kompetensi lulusan didahului dengan mengidentifikasi apa yang hendak diben-tuk, dibangun, dan diberdayakan dalam diri peserta didik sebagai jaminan yang akan mereka capai setelah menyelesaikan pendidikannya pada satuan pendidikan tertentu. Pendekatan kompetensi lulusan menekankan pada kemampuan holistik yang harus dimiliki setiap peserta didik. Hal itu akan membawa implikasi terhadap apa yang seharusnya dipelajari oleh setiap "individu peserta didik, bagaimana cara mengajarkan, dan kapan diajarkannya.

Cakupan kompetensi lulusan satuan pendidikan berdasarkan elemen-elemen yang harus dicapai yang tertuang dalam Permendikbud Nomor 54 Tahun 2013 dapat dilihat dalam Tabel berikut ini.

Tabel 2.1 Kompetensi Lulusan

\begin{tabular}{|c|c|c|c|}
\hline DOMAIN & SD/MI & SMP/MTs & SMA-SMK/MA \\
\hline \multirow[b]{2}{*}{ SIKAP } & \multicolumn{3}{|c|}{ Menerima + Menjalankan + Menghargai + Menghayati + Mengamalkan } \\
\hline & \multicolumn{3}{|c|}{$\begin{array}{c}\text { Pribadi yang beriman, berakhlak mulia, percaya diri, dan bertanggung } \\
\text { jawab dalam berinteraksi secara efektif dengan lingkungan sosial, alam } \\
\text { sekitar, serta dunia dan peradabannya. }\end{array}$} \\
\hline \multirow[t]{2}{*}{ KETERAMPIL } & \multicolumn{3}{|c|}{$\begin{array}{c}\text { Mengamati }+ \text { Menanya }+ \text { Mencoba }+ \text { Mengolah }+ \text { Menyaji }+ \text { Menalar }+ \\
\text { Mencipta }\end{array}$} \\
\hline & \multicolumn{3}{|c|}{$\begin{array}{l}\text { Pribadi yang berkemampuan pikir dan tindak yang efektif dan kreatif } \\
\text { dalam ranah abstrak dan konkret. }\end{array}$} \\
\hline \multirow[t]{2}{*}{ PENGETAHUAN } & \multicolumn{3}{|c|}{$\begin{array}{c}\text { Mengetahui + Memahami + Menerapkan + Menganalisa + } \\
\text { Mengevaluasi }\end{array}$} \\
\hline & \multicolumn{3}{|c|}{$\begin{array}{c}\text { Pribadi yang menguasai ilmu pengetahuan, teknologi, seni, budaya dan } \\
\text { berwawasan kemanusiaan, kebangsaan, kenegaraan, dan peradaban. }\end{array}$} \\
\hline
\end{tabular}

Berdasarkan tabel di atas, cakupan kompetensi lulusan secara holistik yang tertuang dalam Permendikbud Nomor 54 Tahun 2013 dapat dirumuskan sebagai berikut (Peraturan Menteri Pendidikan dan Kebudayaan Nomor 54 Tahun 2013):

1. Kemampuan Lulusan dalam Dimensi Sikap:

Manusia yang memiliki pribadi yang beriman, berakhlak mulia, percaya diri, dan bertanggung jawab dalam berinteraksi secara efektif dengan lingkungan sosial, alam sekitar, serta dunia (Jan peradabannya. Pencapaian pribadi tersebut dilakukan melalui proses: menerima, menjalankan, menghargai, menghayati, dan mengamalkan. 
2. Kemampuan Lulusan dalam Dimensi Keterampilan:

Manusia yang memiliki pribadi yang berkemampuan pikir dan tindak yang efektif dan kreatif dalam ranah abstrak dan konkret. Pencapaian pribadi tersebut dilakukan melalui proses: mengamati, menanya, mencoba, mengo-lah, menyaji, menalar, dan mencipta.

3. Kemampuan Lulusan dalam Dimensi Pengetahuan:

Manusia yang memiliki pribadi yang menguasai ilmu pengetahuan, teknologi, seni, budaya dan berwawasan kemanusiaan, kebangsaan, kenegaraan, dan peradaban. Pencapaian pribadi tersebut dilakukan melalui proses: mengetahui, memahami, menerapkan, menganalisa, dan mengevaluasi.

Selain kompetensi yang bersifat holistis di atas, Kurikulum 2013 juga dilengkapi dengan Standar Kompetensi Lulusan berdasarkan gradasi tingkat satuan pendidikan. Perumusan kompetensi lulusan antar satuan pendidikan mempertimbangkan gradasi setiap tingkatan satuan pendidikan dan memperhatikan kriteria (1) perkembangan psikologis anak, (2) lingkupdan kedalaman materi, (3) kesinambungan, dan (4) fungsi satuan pendidikan. Kompetensi lulusan satuan pendidikan SD/ M1/ SDLB/ Paket A, SMP/ MTs/ SMPLB/ Paket B, SMA/ MA/ SMK/ MAK/Paket C berdasarkan Permendikbud Nomor 54 Tahun 2013. diuraikan masing-masing sebagai berikut.

Lulusan SD/MI/SDLB/Paket A adalah manusia yang memiliki sikap, keterampilan, dan pengetahuan sebagai berikut:

Tabel 2.2 Standar Kompetensi Lulusan SD/MI/SDLB/Paket A

\begin{tabular}{|l|l|}
\hline \multicolumn{1}{|c|}{ DIMENSI } & \multicolumn{1}{|c|}{ KOMPETENSI LULUSAN } \\
\hline SIKAP & $\begin{array}{l}\text { Memiliki perilaku yang mencerminkan sikap orang beriman, berakhlak } \\
\text { mulia, percaya diri, dan bertanggung jawab dalam berinteraksi secara } \\
\text { efektif dengan lingkungan sosial dan alam di sekitar rumah, sekolah, } \\
\text { dan tempat bermain. }\end{array}$ \\
\hline KETERAMPILAN & $\begin{array}{l}\text { Memiliki kemampuan pikir djan tindak yang efektif dan kreatif dalam } \\
\text { ranah abstrak dan konkret sesuai dengan yang ditugaskan kepadanya. }\end{array}$ \\
\hline PENGETAHUAN & $\begin{array}{l}\text { Memiliki pengetahuan faktual dan konseptual dalam ilmu } \\
\text { pengetahuan, teknologi, seni, dan budaya dengan wawasan } \\
\text { kemanusiaan, kebangsaan, kenegaraan, dan peradaban terkait } \\
\text { fenomena dan kejadian di lingkungan rumah, sekolah, dan tempat } \\
\text { bermain. }\end{array}$ \\
\hline
\end{tabular}

Langkah ketiga yang harus dilakukan dalam mengembangkan desain pembelajaran dalam konteks kurikulum 2013 adalah menganalisis siswa dan konteks pembelajaran. Kegiatan ini dapat dilakukan melalui upaya mengenali. Siswa secara mendalam dalam hal kemampuan dan keterampilan awal, sikap, motivasi, bakat, minat, karakter dan kepribadian siswa. Berkenaan dengan analisis konteks pembelajaran, pembelajaran dalam konteks kurikulum 2013 dilakukan dengan berbasis pada standar proses yang telah ditetapkan dalam Permendikbud Nomor 65 Tahun 2013.

\section{METODE PENELITIAN}

Penelitian ini dilakukan dengan metode field research. Pendekatan yang digunakan yaitu triangulation of research, blending or mixing a qualitative and quantitative (Thomas, $\mathrm{R}$. 
Murray, 2003:1-3). Pendekatan qualitative digunakan untuk melihat teori dan konsep kurikulum 2013 yang telah diimplementasikan di madrasah-madrasah secara baik. Pendekatan kuantitatif dipakai untuk mengukur sejauh mana kurikulum 2013 telah terlaksana dengan tepat. Penelitian dilakukan di kabupaten Aceh Selatan. Populasi penelitian adalah seluruh guru Madrasah Ibtidaiyah Negeri se-kabupaten Aceh Selatan. Teknik pemilihan sampel penelitian dilakukan secara random sampling. Sampel penelitian adalah 17 kepala MIN dan 59 orang guru MIN sekabupaten Aceh Selatan. Alur penelitian yang telah dilakukan dapat dilihat pada diagram di bawah ini.

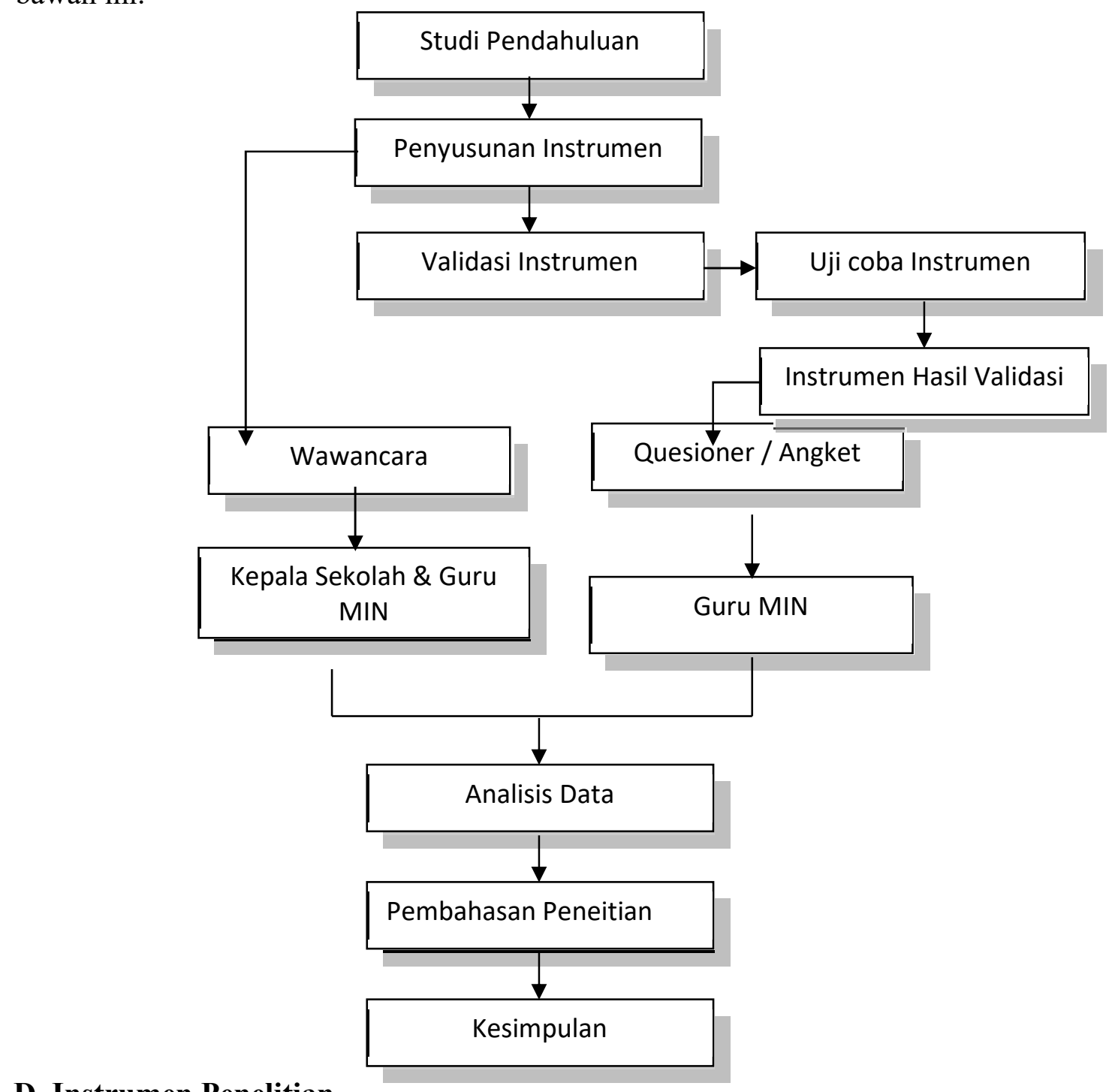

Data yang didapat akan dianalisis berdasarkan jenis data yang diperoleh melalui instrumen yang telah digunakan dalam penelitian. Penelitian ini menggunakan beberapa instrumen yang dirancang untuk mengumpulkan data. Adapun jenis instrumen dan teknik pengumpulan datanya diuraikan pada Tabel 1.

Tabel 1 Jenis Instrumen dan Teknik Pengumpulan Data

\begin{tabular}{|c|c|l|l|l|}
\hline No & $\begin{array}{c}\text { Sumber } \\
\text { data }\end{array}$ & \multicolumn{1}{|c|}{ Data yang diperoleh } & $\begin{array}{c}\text { Teknik } \\
\text { pengumpulan } \\
\text { data }\end{array}$ & \multicolumn{1}{|c|}{ Instrumen } \\
\hline 1 & $\begin{array}{c}\text { Kepala } \\
\text { sekolah }\end{array}$ & $\begin{array}{l}\text { Implementasi Kurikulum } \\
2013\end{array}$ & Wawancara & Lembar wawancara \\
\hline
\end{tabular}




\begin{tabular}{|c|c|l|l|l|}
\hline 2 & Guru & $\begin{array}{l}\text { Implementasi kurikulum } \\
2013\end{array}$ & $\begin{array}{l}\text { Melakukan } \\
\text { pengisian } \\
\text { angket }\end{array}$ & $\begin{array}{l}\text { Angket berhubungan } \\
\text { indikator keberhasilan } \\
\text { kurikulum 2013 }\end{array}$ \\
\hline 3 & Guru & $\begin{array}{l}\text { Kendala atau hambatan } \\
\text { yang dihadapi dalam } \\
\text { pelaksanaan kurikulum } \\
2013\end{array}$ & wawancara & Lembar wawancara \\
\hline 4 & Guru & $\begin{array}{l}\text { Implementasi kurikulum } \\
2013\end{array}$ & Observasi & Lembar Observasi \\
\hline
\end{tabular}

\section{Analisis Instrumen}

Instrumen penelitian yang digunakan untuk mengukur tingkat keberhasilan implementasi kurikulum 2013 yaitu angket. Sebelum instrumen layak digunakan dalam penelitian, maka instrumen terlebih dahulu di uji empirik kepada guru-guru MIN selanjutnya kemudian diuji validitas dengan rumus product moment dan reliabilitas dengan rumus spearman brown. Hasilnya didapat Sebelum divalidasi jumlah pernyataan sebanyak 35 butir dan setelah divalidasi didapatkan 20 pernyataan yang termasuk kategori "Valid". Pernyataan inilah yang digunakan dalam mengukur tingkat keberhasilan kurikulum 2013. Pernyataan yang digunakan berjumlah 20 pernyataan yang terdiri dari 17 pernyataan positif dan 3 pernyataan negatif.

\section{Teknik Analisis Data}

Data yang diperoleh melalui angket kurikulum 2013 selanjutnya direkap dan ditentukan kategorinya. Butir pernyataan berjumlah 20, dengan skala 1-4. Rentang minimummaksimumnya adalah $20 \times 1=20$ sampai $20 \times 4=80$. Luas jarak sebarannya adalah $80-20=60$. Dengan demikian setiap satuan deviasi standarnya bernilai $\sigma=60 / 6=10$ dan mean teoritisnya adalah $\mu=20 \times 2,5=50$. Kategori Indikator keberhasilan kurikulum 2013 dibagi ke dalam 3 bagian yaitu rendah, sedang dan tinggi.

$50-10=40$, Rendah

$50+10=60$, Tinggi

Tabel 2 Kategori Indikator keberhasilan Kurikulum 2013

\begin{tabular}{|c|c|}
\hline Rentang Skor & Kategori Keberhasilan Kurikulum 2013 \\
\hline $60-80$ & Tinggi \\
\hline $41-59$ & Sedang \\
\hline $20-40$ & Rendah \\
\hline
\end{tabular}

\section{HASIL DAN PEMBAHASAN}

Setelah hasil jawaban angket di rekap dan dijumlahkan kemudian ditentukan kategori keberhasilan implementasi kurikulum 2013. Berdasarkan hasil angket dapat diketahui tingkat keberhasilan kurikulum 2013 dengan kategori 6,78\% "Tinggi”, 69,5\% kategori "Sedang" dan 6,78\% kategori "Rendah". Persentase kategori tingkat keberhasilan kurikulum 2013 di Madrasah Ibtidaiyah Negeri kabupaten Aceh Selatan dapat dilihat pada diagram di bawah ini. 


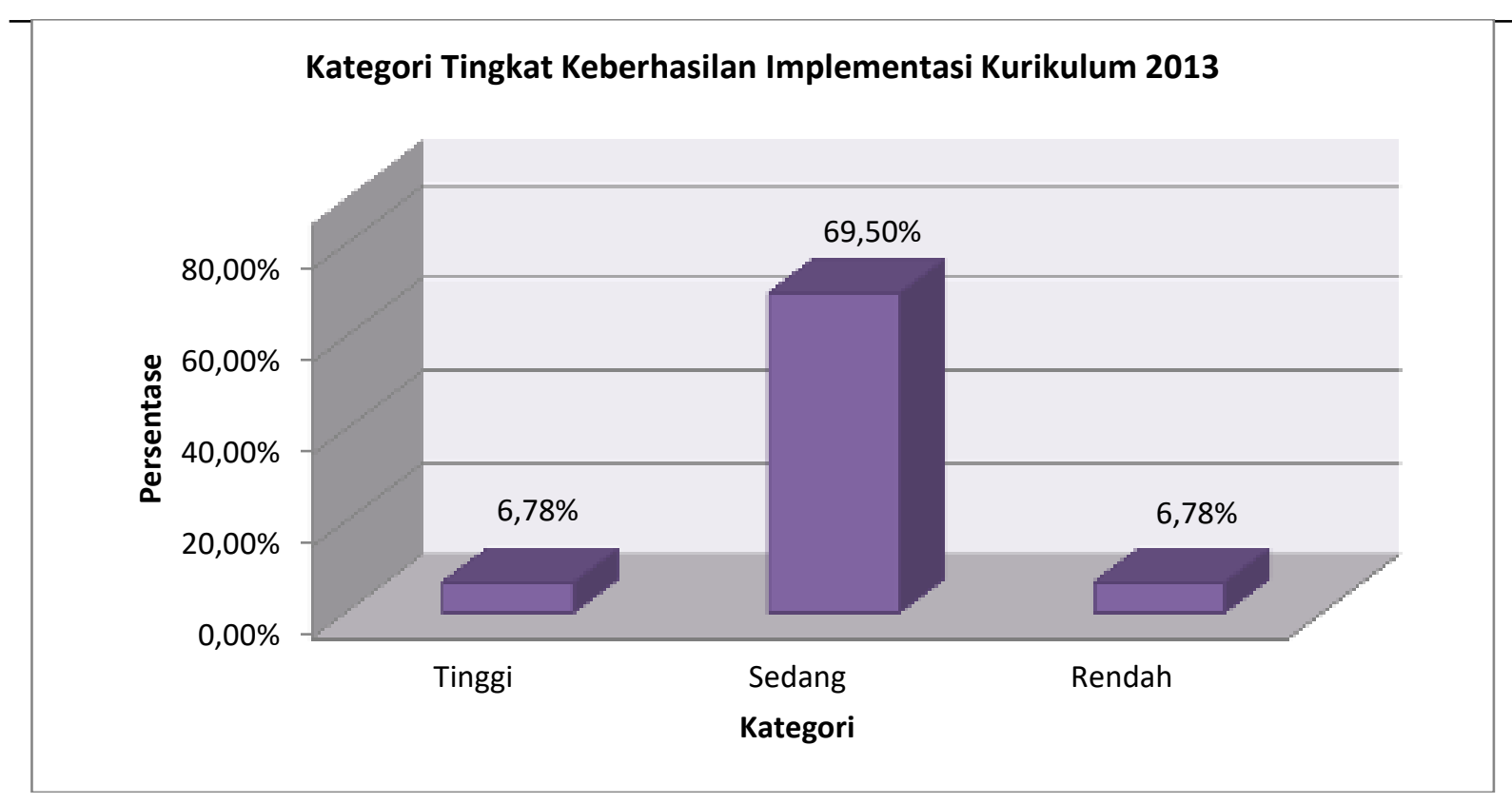

Gambar 1. Diagram Tingkat Keberhasilan Kurikulum 2013 di Kabupaten Aceh Selatan

Diagram di atas menunjukkan bahwa tingkat keberhasilan implementasi kurikulum 2013 di MIN se-kabupaten Aceh Selatan berada pada kategori "sedang". Kategori ini menginterpretasikan bahwa di MIN se-kabupaten Aceh Selatan sudah melaksanakan kurikulum 2013 pada proses pembelajaran, akan tetapi belum terlaksana secara menyeluruh pada setiap mata pelajaran di setiap tingkatan (kelas). Selama ini kurikulum 2013 yang telah dilaksanakan masih belum sempurna sebagaimana pelaksaanaan kurikulum 2013 yang seharusnya. Hal ini disebabkan karena kurangnya kemampuan guru dalam menguasai informasi dan tekhnologi (IT). Selain itu guru juga masih kurang memahami tentang teknik penggunaan metode, media dan alat pembelajaran yang sesuai dengan materi bahan ajar. Selain melalui angket, data juga dikumpulkan dengan observasi yang dilakukan oleh observer. hasil observasi dapat dilihat pada tabel di bawah ini:

Tabel 4.22 Hasil Olah Data Observasi Penelitian

\begin{tabular}{|c|l|c|c|}
\hline \multirow{2}{*}{ No } & \multicolumn{1}{|c|}{ Implementasi Kurikulum 2013 } & \multicolumn{2}{|c|}{ Persentase } \\
\cline { 3 - 4 } & \multicolumn{1}{|c|}{ Ya } & Tidak \\
\hline 1 & Guru merancang RPP sesuai dengan RPP kurikulum 2013 & $29 \%$ & $71 \%$ \\
\hline 2 & $\begin{array}{l}\text { Buku pegangan guru dalam mengajar adalah buku kurikulum } \\
2013\end{array}$ & $82 \%$ & $18 \%$ \\
\hline 3 & Guru menggunakan Infokus dalam mengajar & $24 \%$ & $76 \%$ \\
\hline 4 & Penilaian siswa menggunakan aplikasi & $0 \%$ & $100 \%$ \\
\hline 5 & Isi rapor yang digunakan sesuai dengan format kurikulum 2013 & $0 \%$ & $100 \%$ \\
\hline 6 & Sampul Rapor yang digunakan sudah sesuai kurikulum 2013 & $100 \%$ & $0 \%$ \\
\hline 7 & Guru menggunakan Media dalam mengajar & $18 \%$ & $82 \%$ \\
\hline
\end{tabular}

Berdasarkan observasi oleh observer diketahui bahwa 29\% guru merancang RPP sesuai dengan kurikulum 2013 sedangkan 71\% guru belum merangcang RPP sesuai dengan 
kurikulum 2013. Selama ini guru sudah mulai menggunakan buku ajar/pegangan dalam mengajar yaitu buku kurikulum 2013 yaitu sebesar 82\% sedangkan 18\% belum menggunakan buku pegangan yang sesuai dengan kurikulum 2013. Hal ini sebabkan terbatasnya keberadaan buku tersebut serta belum adanya bantuan buku dari pemerintah.

Dalam melaksanakan pembelajaran guru belum menggunakan infokus, ini diketahui berdasarkan hasil observasi yaitu sebesar $76 \%$ sedangkan $24 \%$ lainnya guru sudah mulai menggunakan infokus. Infokus yang terbatas menyebabkan sebagian guru lebih banyak melaksanakan pembelajaran tanpa infokus. Dilihat dari segi evaluasi pembelajaran yaitu berupa pengisian nilai siswa masih belum menggunakan aplikasi untuk penilaian sesuai kurikulum 2013 yaitu sebanyak 100\% guru masih belum menggunakan aplikasi. Dengan demikian isi rapor siswa masih 100\% masih belum sesuai format kurikulum 2013 melainkan masih menggunakan format KTSP.

Berbeda halnya dengan isi rapor dan aplikasi, sampul rapor siswa $100 \%$ sudah menggunakan sampul sesuai dengan kurikulum 2013. Dari segi penggunaan media pembelajaran, baru $18 \%$ guru menggunakan media pembelajaran sedangkan $82 \%$ guru tidak menggunakan media dalam mengajar.

\section{Pembelajaran dan kendala-kendala yang dihadapi guru dalam Implementasi Kurikulum 2013}

Untuk pelaksanaan pembelajaran kurikulum 2013 di MIN se-kabupaten Aceh Selatan, tim peneliti melakukan interview langsung dengan kepala dan guru MIN di kabupaten Aceh Selatan. Hasil Interview dapat dilihat di bawah ini.

Informasi awal didapatkan peneliti dari kepala MIN 14 Kabupaten Aceh Selatan menurut informan "Kepala MIN di kabupaten Aceh Selatan pernah mengikuti acara sosialisasi tentang implementasi kurikulum 2013 yang dilaksanakan oleh Kementerian Agama Republik Indonesia Kabupaten Aceh Selatan dan bekerja sama dengan penerbit Buku MAS MEDIA." Para kepala di MIN di Aceh Selatan sudah pernah mengikuti sosialisasi tentang kurikulum 2013. kegiatan sosialisasi tersebut dikhususkan pada mata pelajaran Pendidikan Agama Islam (PAI) dan diikuti oleh seluruh kepala MIN selama tiga hari.

Kurikulum 2013 di MIN Kabupaten Aceh Selatan mulai diterapkan sejak tahun 2015, dan mata pelajaran yang menerapkan kurikulum 2013 adalah mata pelajaran PAI untuk semua kelas mulai dari kelas 1 sampai kelas 6, sedangkan untuk mata pelajaran lainnya belum siap untuk diterapkan, mengingat masih kurangnya Sosialisasi kurikulum 2013 untuk bidang studi lain dan masih terbatasnya penguasaan IT yang dimiliki guru.

Informasi selanjutnya diperoleh dari Kepala MIN 13 "Kepala MIN baru satu kali ikut pelatihan kurikulum 2013. MIN 13 Kabupaten Aceh Selatan sudah menerapkan kurikulum 2013 selama 3 tahun untuk semua mata pelajaran yaitu mulai dari kelas satu sampai dengan kelas tiga, sedangkan kelas yang lainnya masih menggunakan KTSP. Hal ini disebabkan karena masih kurangnya sosialisasi dan pemahaman guru tentang kurikulum 2013.

"Untuk buku pengangan guru ada yang KTSP dan ada juga yang kurikulum 2013." Dalam melaksanakan proses belajar mengajar, guru masih menggunakan buku paket KTSP yang dipadukan dengan kurikulum 2013, hal ini dikarenakan pengadaan buku-buku paket Kurikulum 2013 masih sangat minim dan belum memadai. Pada mata pelajaran dan kelas yang belum memiliki buku paket kurikulum 2013, maka guru menggunakan buku paket KTSP.

Lebih lanjut Menurut Bapak Teuku Darni sebagai kepala MIN 7 sekaligus sebagai Ketua K3M MI Aceh Selatan, menyatakan bahwa K3M MI pernah membuat pelatihan untuk guru tentang pelaksanaan kurikulum 2013. Guru MIN di Aceh Selatan pernah diundang untuk diberikan pelatihan tentang kurikulum 2013, akan tetapi untuk implementasi Kurikulum 2013 
di MIN hanya baru pada mata pelajaran PAI saja dan baru dilaksanakan pada kelas 1 MIN, sedangkan untuk kelas lain masing menggunakan kurikulum KTSP.

Perangkat pembelajaran untuk penunjang pelaksanaan kurikulum 2013 sudah ada walaupun belum memadai secara maksimal. Kegiatan pelatihan khusus tentang praktek kurikulum 2013 di MIN yang beliau pimpin juga sudah pernah dilaksanakan, walaupun tidak ada anggaran khusus untuk kegiatan sosialisasi pelaksanaan kurikulum 2013 di Sekolah.

Informasi selanjutnya sosialisasi penerapan kurikulum 2013 sudah pernah dilaksanakan di Banda Aceh khusus pada mata pelajaran PAI. Secara umum, guru-guru MIN di Aceh Selatan sudah pernah mengikuti sosialisasi penerapan kurikulum 2013 baik yang dilaksanakan di dalam daerah maupun yang dilaksanakan di luar daerah. Dari hasil mengikuti kegiatan tersebut guru mendapatkan informasi tentang kurikulum 2013, akan tetapi bukan dalam bentuk pelatihan implementasi pembelajaran atau praktek pelaksanaan proses belajar mengajar kurikulum 2013.

Buku pembelajaran yang digunakan masih berupa buku KTSP dan ada juga sebagian yang menggunakan buku kurikulum 2013 seperti pada mata pelajaran agama dan khusus bagi kelas 1 dan kelas 2. Selanjutnya alat dan media pembelajaran yang menjadi pendukung pelaksanaan pembelajaran Kurikulum 2013 belum lengkap dan belum memadai di MIN tersebut, sehingga hal ini menjadi kendala bagi para guru dalam mengimplementasikan kurikulum 2013.

Teknik atau metode Proses belajar mengajar di MIN Kabupaten Aceh Selatan sudah menerapkan kurikulum 2013, akan tetapi teknik evaluasi masih menggunakan KTSP. Rapor 2013 sudah ada dan sudah digunakan pada setiap MIN, akan tetapi hanya pada sampul rapornya saja yang memperlihatkan kurikulum 2013, sedangkan isinya yang didapati oleh peneliti masih menunjukan bentuk evaluasi KTSP, jadi belum sepenuhnya menggunakan Rapor kurikulum 2013.

Hal di atas menunjukan bahwa Kurikulum 2013 di MIN Kabupaten Aceh Selatan hanya baru diterapkan pada mata pelajaran PAI dan itu baru sebatas metodenya saja, dan belum diimplementasikan sampai ke tahap evaluasi. Sebagaimana telah dijelaskan sebelumnya bahwa proses evaluasi pembelajaran masih menggunakan kurikulum KTSP.

Sebagian MIN memang telah mendapatkan aplikasi teknik evaluasi pembelajaran Kurikulum 2013, akan tetapi para guru belum memahami dengan baik bagaimana cara menggunakannya, hal ini menjadi kendala bagi para guru ketika melakukan kegiatan evaluasi karena berbeda bentuk penilaian dan bentuk aplikasi antara KTSP dan Kurikulum 2013. Hal ini disebabkan karena pada saat sosialisasi tentang implementasi kurikulum 2013, penggunaan aplikasi penilaian atau evaluasi tersebut belum dijelaskan secara maksimal dan belum memadai sehingga guru masih sangat kesulitan dalam penerapannya.

Informasi di atas tadi di dukung informasi yang didapatkan dari MIN 27 kabupaten Aceh Selatan, yang menjelaskan bahwa kurikulum 2013 juga baru diterapkan pada mata pelajaran PAI. Buku kurikulum 2013 baru tersedia hanya untuk kelas satu, untuk kelas yang lainnya masih menggunakan buku KTSP. Kemudian, Fasilitas yang mendukung pelaksanaannya kurikulum 2013 juga belum memadai. Rapor yang digunakan di MIN 27 sudah rapor dalam bentuk kurikulum 2013 akan tetapi teknik evaluasi dan model penilaiannya masih dalam bentuk KTSP.

Informasi terakhir yang peneliti dapatkan di MIN 20 kabupaten Aceh selatan memiliki beberapa kendala dalam pelaksanaan kurikulum 2013 karena sosialisasinya masih tingkat pengenalan belum ke tahap penerapan atau implementasinya yang masih sangat minim. Mata pelajaran yang mendekati untuk diimplementasikan kurikulum 2013 adalah pada mata pelajaran Pendidikan Agama Islam sedangkan mata pelajaran yang lainnya belum memadai untuk dilaksanakan. Selanjutnya, kemampuan guru dalam mengimplementasikan Kurikulum 
2013 belum maksimal karena terbatasnya pelatihan-pelatihan tentang pelaksanaan pembelajaran Kurikulum 2013.

Pelatihan kurikulum 2013 sudah pernah ada dibuat oleh kemenag yang diundang kepala sekolah dan yang dilatih guru kelas bukan guru bidang studi. Buku kelas kurikulum 2013 sudah ada kelas 1 tema sampai 4,5 dan 6. Aplikasi rapor masih KTSP sehingga untuk penilaian masih menggunakan KTSP. Mau menggunakan kurikulum 2013 akan tetapi masih bingung pada implemenatsinya, sedangkan mau menggunakan KTSP tidak dapat dipergunakan lagi.

Berdasarkan hasil wawancara diatas dapat diketahui bahwa implementasi kurikulum 2013 di MIN se-kabupaten Aceh Selatan sudah dilaksanakan secara serentak pada tahun 2015. meskipun sudah dilaksanakan selama tiga tahun, akan tetapi pelaksanaannya masih terbatas pada mata pelajaran PAI. sedangkan untuk mata pelajaran lain belum menggunakan kurikulum 2013 hal ini disebabkan terbatasnya sosialisasi untuk mata pelajaran umum dan minimnya ketersediaan buku-buku penunjang.

Sosialisasi yang diikuti oleh perwakilan guru dan kepala MIN selama ini hanya sebatas penyampaian informasi tentang kurikulum 2013. Informasi yang didapatkan oleh perwakilan guru selanjutnya diteruskan kepada guru-guru yang lain di madrasah, sehingga guru-guru di MIN secara keseluruhan tidak mendapatkan informasi yang utuh, hal ini menjadi kendala bagi guru dalam memahami pelaksanaan kurikulum 2013 dengan benar. Seharusnya sosialisasi yang diberikan harus diikuti oleh semua guru sehingga informasi yang didapatkan utuh, baik dari segi teori maupun cara menyusun perangkat pembelajaran, metode atau teknik dalam proses belajar mengajar serta sistem evaluasi pembelajaran yang sesuai dengan kurikulum 2013.

Sistem evaluasi pembelajaran kurikulum 2013 menggunakan aplikasi yang telah didesain khusus yang harus diisi dengan menggunakan komputer atau laptop. terbatasnya kemampuan guru dalam mengaplikasikan komputer, maka hal tersebut menjadi kendala bagi guru dalam mengaplikasikan sistem evaluasi kurikulum 2013 dan mendesain perangkat pembelajaran. Sehingga rapor yang digunakan di MIN Aceh Selatan covernya dalam bentuk kurikulum 2013, akan tetapi format form penilaiannya masih menggunakan bentuk KTSP.

Guru merupakan pelaku utama dalam terlaksananya kurikulum 2013, oleh sebab itu guru seharusnya adalah orang yang pertama dan diutamakan untuk dapat memahami tentang bagaimana implementasi kurikulum 2013 melebihi praktisi pendidikan lainnya. Akan tetapi fakta di lapangan menunjukkan kurangnya kesiapan guru dalam dalam implementasi kurikulum 2013. Hal ini menjadi kendala yang serius dalam proses implementasi kurikulum 2013 dan manjadi "PR" yang harus segera terjawab sehingga menemukan solusi yang tepat demi tercapainya tujuan pendidikan nasional. 


\section{PENUTUP}

1. Tingkat keberhasilan implementasi kurikulum 2013 Tingkat pendidikan MIN di Kabupaten Aceh Selatan saat ini berdasarkan hasil analisis data angket berada pada kategori "Sedang" dengan persentase 69,5\%.

2. Pelaksanaan pembelajaran kurikulum 2013 di MIN se-Kabupaten Aceh Selatan sudah berjalan selama 3 tahun khusus pada mata pelajaran Pendidikan Agama Islam (PAI). Meskipun demikian, pelaksanaannya baru diterapkan di kelas 1 sampai kelas 3 MIN. Perangkat pembelajaran yang digunakan oleh guru MIN sebagian menggunakan kurikulum 2013 dan sebagiannya lagi masih menggunakan KTSP. Rapor yang dipakai di MIN Aceh Selatan sudah bercover kurikulum 2013 akan tetapi format form penilaian masih menggunakan bentuk KTSP.

3. Adapun kendala-kendala yang dihadapi oleh guru-guru MIN di Kabupaten Aceh selatan adalah kurangnya pemahaman guru tentang implementasi proses belajar mengajar, kurangnya kemampuan guru dalam desain perangkat pembelajaran, terbatasnya sarana dan prasarana pendukung yang tersedia di MIN, terbatasnya kemampuan guru dalam penguasaan IT serta kurangnya keterampilan guru dalam mengaplikasikan model evaluasi kurikulum 2013. 


\section{DAFTAR PUSTAKA}

E. Mulyasa. (2016). Pengembangan dan Implementasi Kurikulum 2013, Bandung: Remaja Rosdakarya.

Fadhil Sidiq. (2015). Analisis Kesiapan Guru dalam Implementasi Kurikulum 2013 di MIN seBanda Aceh". UNIMED.

Imas Kurinasih dan Berlin Sani. (2014). Implementasi Kurikulum 2013 Konsep dan Penerapan. Surabaya: Kata Pena.

Ismail Suardi wekke dan Ridha Windi Astuti. (2007). Kurkikulum 2013 di Madrasah Ibtidaiyah: Implementasi di Wilayah Minoritas Muslim” Tadris Jurnal Keguruan dan Ilmu Tarbiyah, Juni, Vol 1, Nomor 2.

Julia Brannen. (1993). et.al.,Mixing Methods:Qualitative and Quantitative Research. Sidney:Avebury.

Peraturan Menteri dan Kebudayaan Republik Indonesia Nomor 65 Tahun 2013 tentang Standar Proses.

Peraturan Menteri Pendidikan dan Kebudayaan Nomor 54 Tahun 2013 Tentang Standar kompetensi Lulusan Pendidikan Dasar dan Menengah.

Thomas, R. Murray. (2003). Blending Qualitative and Quantitative Research Methodes in Theses and Dissertation. California:Corwin Press.

Undang-Undang SISDIKNAS Nomor 20 Tahun 2003. (2006) Jakarta: Sinar Grafika.

Zainal Arifin. (2012). Konsep dan Model Pengembangan Kurikulum. Bandung: Remaja Rosdakarya. 